\title{
Retaining and Developing Quality Teachers: Critical \\ Issues for Administrators in Nigeria Secondary Schools
}

\author{
Chinelo O. Duze (Ph.D.) \\ Department of Educational Administration \& Policy Studies, Delta State University, Abraka, \\ Nigeria \\ Email: Chineloduze@yahoo.com \\ Ogbah, Rosemary \\ Department of Educational Administration \& Policy Studies, Delta State University, Abraka, \\ Nigeria
}

Accepted: Jan 17, 2013 Published: Feb 23, 2013

Doi:10.5296/jsr.v4i1.3296 URL: http://dx.doi.org/10.5296/jsr.v4i1.3296

\begin{abstract}
The study explored the art of retaining and developing quality teachers, with emphasis on critical issues for school administrators in Nigeria. In a country where there are hues and cries everywhere about the falling standard in education, supported by ample research evidence, it becomes pertinent to review literature on teacher retention and development, a factor that is accepted globally to influence school environment and thus goal attainment in education. This will bring again to the limelight critical issues and their implications for better school outcomes as it affects teacher-staffing. It will enable stakeholders in Nigeria education to have a re-think about the way and manner teachers are handled in Nigeria secondary schools and begin to do the things they ought to do to redeem the school system. In this light, relevant literature was reviewed on theoretical retention strategies; the importance of comprehensive induction on teachers' retention and development; how improved working conditions can retain quality teachers; the role of administrators in teachers' retention and development; problems facing school principals in teachers' retention and development; support needed by school principals in the retention and development of teachers, and what the Nigerian teachers need to be retained in schools. Based on this discourse, it was recommended that government in collaboration with school principals should provide comprehension induction to teachers; school principals should ensure that the school climate is supportive of teaching and learning, encourage interpersonal relationship between staff and students, promote school/community relationship, involve teachers in decision making, ensure a manageable student-teacher ratio, and reduce teachers' workload; State School Boards should enforce policies that provide for equitable distribution of learning materials to teachers and students in schools; government should grant additional incentive to teachers in rural and isolated
\end{abstract}


schools and train school principals to be familiar with the available resources to support the diverse needs of students and staff.

Keywords: Teacher Quality, Retention, Development, School Administrators, Nigeria

\section{Introduction}

Teachers touch the lives of all children from a variety of backgrounds, including those from families that exhibit a wide range of cultural and linguistic diversity. Teachers also touch the lives of children with varying ability levels, including those with significant disadvantages, such as poverty, parental and societal neglect, as well as intellectual, social and physical disabilities. Generally, quality teachers are those teachers that students remember and cherish forever. Such teachers have long-lasting impacts on the lives of students. They have good classroom management skills and ensure good student behaviour, effective study and work habit. They also possess the knowledge of the subject matter they teach, they are prepared to answer questions and make lessons interesting for students. Nevertheless, some teachers tend to leave the teaching profession to other jobs or transfer from one school to another, putting those most vulnerable children and youths at risk of failing to realize opportunities afforded to them through quality education.

Understanding why teachers leave is the first step in getting them to stay. Most times, teachers leave when they encounter environments that lack essential professional supports. These include: Job dissatisfaction; poor working conditions and low salary; inadequate support from parents, administration, colleagues and the public; discipline, management and attendance problems; increasing class size; increased in workloads; poor motivation of students; and lack of space for teachers to participate in key decisions effecting the school. Another reason is lack of induction and mentoring programmes for new and experienced teachers (Ingersoll and Smith, 2004).

The complexity of the issues embedded in retaining high quality teachers, made administrators find addressing these essential issues to be a daunting task. It is therefore paramount to assist administrators in planning, implementing, evaluating a high quality teacher retention initiative that will help keep the best teacher in their schools. Retention is referred to as the ability of organization to retain its employees. It could also be considered as relating to the efforts by which employers attempt to retain their workforce.

Quality teachers, as studies have consistently shown, are teachers who are better trained, more experienced and licensed in the subject they teach (Mayer, Mullens and Moore, 2000). Development are planned activities which focus on increasing and enlarging the capacities of employees so that they can successfully handle greater and / or assume higher position in the organisation's hierarchy to better handle current responsibilities. It has been known by several names including human resource development and learning and development 
(Harrison, 2005). The art of retaining and developing quality teachers is therefore pivotal to school administrators to the success of secondary schools.

\section{REVIEW OF RELATED LITERATURE}

\section{Theoretical Retention Strategies}

According to Scholl (2002), Vroom Expectancy theory provided some guidance for retaining employees. These are: Valence, Expectancy and Instrumentality. These components work together to establish a motivational force.

Valence is the degree to which the rewards offered by an organization align with the needs employees seek to fulfill. High valence indicates that the needs of employees are aligned well with the rewards system an organization offers. Conversely, low valence is a poor alignment of needs with the rewards and can lead to low job satisfaction and thereby increase turnover and decrease retention. Valence is therefore the expected satisfaction a person receives from a particular outcome (Redmond, 2010).

Expectancy has several factors that can lead to high job satisfaction and high retention rates for organizations. Examples are ability and interest. Lack of ability and interest will decrease a person's expectancy. Increasing expectancy in an organization can be done by management discovering what resources, supervision, and training employees need to make them to be more confident in their abilities (Redmond, 2010). Instrumentality is the perception of employees whether they will actually get what they desired even if it has been promised by the manager. Increasing instrumentality within an organization will be part of implementing an effective rewards system for attainment of specific goals and accomplishment. The variables affecting instrumentality are trust in leaders, control and policies (Scholl, 2002).

Retention has a direct and causal relationship with employee needs and motivation. Applying a motivation theory model, such as Maslow's Hierarchy of Needs, is an effective way of identifying effective retention protocol. An alternative motivation theory to Maslow's Hierarchy of Needs is the Motivator-Hygiene (Herberg's) theory. While Maslow's Hierarchy implies the addition or removal of the same need stimuli will enhance or detract from the employee's satisfaction, Herzberg's findings indicate that factors garnering job satisfaction are separate from factors leading to poor job satisfaction and employee turnover. Herzberg's system of needs is segmented into motivators and hygiene factors. Like Maslow's Hierarchy, motivators are often unexpected bonuses that foster the desire to excel. Hygiene factors include expected conditions that if missing will create dissatisfaction. For instance, appropriate tools for a given job. Employers must utilize positive reinforcement methods while maintaining expected hygiene factors to maximize employee satisfaction and retention (Spector, 1985). 
Reducing the frequency with which children are taught by a successive stream of novice teachers may be one step toward improving educational quality. Steff, Wolffe, Pasch and Enz (2000:6) reviewed the literature on the life cycle of a teacher and the time it takes for a new teacher to become proficient. They concluded:

The apprentice phase begins for most teachers when they receive responsibility for planning and delivering instruction on their own. This phase continues until integration and synthesis of knowledge, pedagogy, and confidence merges, marking the beginning of the professional period. Typically, the apprentice phase includes the induction period and extends into the second or third year of teaching.

To Steff et al., (2000), teacher retention initiatives are often based on this recognized need to keep in classrooms those teachers who are qualified and utilize effective teaching strategies, demonstrated by increased student achievement year after year. A teacher workforce that is well trained, engaged in continuing professional development, and committed to staying in the state, district and school will result in all students receiving appropriate instruction and increasing their achievement. Therefore, administrators assuming leadership of a retention effort as part of a long-range plan for developing the district's teaching force is an important first step.

\section{The Importance of Comprehensive Induction in Teachers' Retention and Development}

There is growing consensus that the single most important factor in determining student performance is the quality of the teacher. Therefore, if the national goal of providing an equitable education to children across this nation is to be met, it is critical that efforts be concentrated on developing and retaining high-quality teachers in every community and at every grade level. A solution to the problem of keeping good teachers in the classroom does exist. The comprehensive induction for instance, is designed to provide new teachers with the practical skills they need for success. Comprehensive induction is a combination of mentoring, professional development, support and formal assessments for new teachers during at least their first two years of teaching. In addition, comprehensive induction helps to develop novice teachers into high-quality professionals who improve student achievement. Most researchers and education experts agreed that, in general, new teachers need three to seven years in the field to reach proficiency and maximize their students' performance (Berliner, 2000; Cleycomb and Hawley, 2000). Comprehensive induction can minimize the time it takes for new teachers to perform at the same level as an experienced teachers (Villar, 2004). This, according to Villar (2004) includes a number of components:

- High-quality mentoring: This is a structured mentoring from a carefully selected teacher or teachers who work in the same field or subject as the new teacher. They are trained to coach new teachers, and can help improve the quality of teachers' practice. Mentors guide and support the work of novice teachers by observing them in the 
classroom, offering them feedback, demonstrating effective teaching methods, assisting with lesson plans, and helping teachers analyze student work and achievement data to improve their instruction.

- Common planning time: Regularly scheduled common planning time helps teachers to connect what and how they teach to improving student achievement in a collaborative culture. These strategies may include how to develop lesson plans, use student assessment data, and employ collaborative models to increase student achievement.

- Ongoing professional development: These activities include, regular seminars and meetings that improve a teacher's skill to increase student learning. Professional development should meet teachers' needs to expand content knowledge, teach literacy and numeracy at the secondary school level, address diverse learning needs, and manage student behavior.

- An external network of teachers: Participation in a network of educators outside of the local school provides teachers with a community of colleagues within which to collaborate and receive support, keeping them from feeling isolated.

- Standards-based evaluation: Some new teachers may not be ideally suited for teaching. Standards based evaluation of all beginning teachers provides a mechanism for determining whether or not new teachers should move forward in the profession.

\section{Improved Working Conditions Can Retain Quality Teachers}

The climate within a school building and the workforce conditions it encompass acts as either a support or a deterrent for teacher retention. Workforce conditions that encourage the capabilities and emphasize the worth of individuals, contribute to retention (Council for Exceptional Children (CEC), 2001). To CEC, (2001), School climate and working conditions include: teacher decision-making practices regarding both instruction and school governance issues; enforce student discipline policies; incorporate professional development opportunities; strive for teaching assignments aligned with certification and background; provide extra compensation for difficult and time consuming duties; facilitate the sharing of knowledge and skills among new, mid-career and more experienced teachers. Likewise, the availability of material resources for all teachers impacts feelings of satisfaction and self-efficacy. These feelings play an important role in a teacher's decision to stay, move on to another assignment, or leave the field of teaching. School districts with policies that provide for equitable distribution of resources to all teachers have a greater opportunity of retaining all teachers, especially in hard-to-fill positions.

Research on the impact of teachers' salaries also indicates that, although salary is not the reason that teachers generally come into teaching, it can be a significant factor in a teacher's decision to move to another district, assignment or profession (Southern Regional Education Board, 2002). For instance, a Special Education, Mathematics, or Science teacher who 
encounters poor working conditions, including low pay and lack of support from leaders, is more likely to leave than one who finds a climate of collegiality and supports that are both material and financial.

\section{The Role of the Administrator in Teacher Retention and Development}

Research indicates that administrative leadership is the most important factor in determining the climate of a school, and there are specific leader activities that allow all teachers to feel supported in their work. Not only do these activities and supports facilitate the maintenance of professional relationships within a school, they also provide needed resource for effective teacher practice (Dipaola and Walther, 2003).

The Philadelphia Education Fund Study by Useem (2001) noted that schools that had a low turnover of teachers had principals who demonstrated the following skills and management styles:

- Implementing a strong induction programme that reflected the principal's personal involvement in meeting with new teachers, having her/his office open for conversations, assigning new teachers classroom rosters that were not heavily weighted with challenging students, and providing mentors early in the school year;

- Overseeing a safe and orderly school environment with active support for teachers on disciplinary issues;

- Maintaining a welcoming and respectful administrative approach toward all staff, the children, their parents and school visitors;

- Developing the leadership skill of school staff; and

- Providing materials and supplies to all teachers in a consistent, timely and inclusive manner.

Other ways in which school principals can promote teachers' retention include:

\section{Leadership/ Decision Making}

The decisions that school leaders make and how they make them have a direct impact on working conditions. Teachers often complain that decisions affecting them are usually made without their knowledge. Leaders need to involve teachers in making decisions. For example, leaders can involve staff in departmental scheduling, student scheduling and duty assignments (Price, 2003). Administrators must be familiar with available resources to support the diverse needs of students, families and staff and must know how to access additional support in order to ensure appropriate education for all students and support for teachers. For example, leaders can make sure English as a second language and bilingual programmes are effectively supported (Dipaola and Walther, 2003). They can make special education concerns integral when planning for professional development, distribution of materials, books, classroom space and equipment. They can ensure that special education is 
not put at the end of the line as an afterthought (Council for Exceptional Children, 2000). Also, compensation plays a major role in retaining teachers. School leaders should develop teacher compensation packages that demonstrate that they are valued. Leaders can use salaries and bonuses as incentives to retain teachers. They also can put together a team of administrators and teachers to develop an incentive pay program

\section{School Climate}

Teachers and students will do their best work in a healthy, pleasant environment. School leader need to ensure a positive school climate and make the school a place where people want to be (Price, 2003). The school will not be the kind of place where teachers want to be if they do not trust the administration. To develop trust among teachers and all stakeholders (parents, students, community members, central office staff and school board members), leaders must be honest and up-front with them. Leaders can be visible to staff, students and parents in classrooms, in the corridors, at lunch, at bus duty, and at extracurricular activities (Hopkins, 2000).

Concerns over safety and disciplines are two of the major reasons teachers leave the jobs or schools. By developing consistent student behavior policies and addressing safety and discipline issues, much can be accomplished. Leaders can work to stop bullying and harassment. They can expand access to counseling, anger management and peer mediation. They can provide ways for students to communicate with adults about rumors and threats. Leaders can teach respect and responsibility and expand opportunities for students to work with adult role models (National Education Association, 2003)

\section{Infrastructure}

Fieldings and Simpson, (2003), noted that if schools are to succeed in retaining teachers, proper infrastructure should be in place that allows teachers to focus most of their time and energy on teaching. Therefore, school leaders should give teachers less of a workload, fever responsibilities and duties so that they can concentrate on their classrooms and student. Leaders should reduce this burden by such strategies as turning the task over to assistant principals. Leaders also must ensure that teachers have adequate resources and materials to do their jobs and sufficient common planning time should be built into the schedules of classroom teachers and specialists so they can address instructional needs and classroom concerns (Dipaola and Waither, 2003).

\section{Content/ Skills}

The research is clear that students learn best from high quality teachers who know the subject matter and how to deliver it. Ensuring that teachers are competent and have opportunities to improve students' skills is critical. The school leader needs to be an instructional leader and communicate views on what is considered good teaching, as well as expectations for 
instructional practices grading and student achievement. Administrators should share, model and encourage best practice experimentation. Giving immediate feedback through comments or notes and being available for short, spontaneous counseling sessions are seen by teachers as being very supportive. For special educators, school leaders should have a working knowledge of Individual with Disabilities Education Act (IDEA) and No Child Left Behind (NCLB) so they can communicate with staff, families and the community regarding special education issues (Dipaola and Walther, 2003)

\section{Community Involvement and Support}

School leaders need to look for ways to involve the community. They can involve families and the community when addressing safety and discipline issues including the establishment of school safety committee that includes community representative to gather and analyze data, put together and implement a plan and monitor its results (National Education Association, 2003). School leaders should go beyond simply involving the community and create relationships among the school, families and the community, leaders can visit families at home when possible. They can become familiar with business people and community organizations and ask them if they could help create learning experiences for students. Leaders can seek to make available health, social, mental health, counseling and other family services in the school and increase the number of adults in the building to provide care and guidance for students. Leaders can generate a broad set of activities in which family and community members can participate and contribute their talents to the school (Ferguson, 2003; Duze, 2011b). Most educators and parents have had no training on how to work with one another, and many fear and avoid one another. School leaders should consider providing staff and parents with ongoing research based training on how to work together and create non-threatening social activities to bring them together (Wherry, 2003).

\section{Problems Facing School Principals in Teacher Retention and Development}

Although, it is pivotal for school principals to retain great or quality teachers in the school, they are faced with the following problems as deduce from the National Board Certified Teachers (NBCTs) summits with policy makers held in North Carolina, Ohio, Oklahoma, South Carolina and Washington (Barnett, Raspberry and Williams, 2007: 6-13 ).

- Schools have dearth of up-to-date technology and an inadequate infrastructure for introducing students to $21^{\text {st }}$ century tools. Resources are not distributed equitably. There are schools with everything and schools with nothing.

- The recommendation by the NBCTs at the policy summits was that incentives should be based on proficiency. Since the system they are operating on was No Child Left Behind, and it does little to encourage effective teaching, this will pose a problem to principals because the system can consequently discourage teachers from moving to high-needs schools, where challenges are greater and bonuses more difficult to earn. 


\section{MInstitute Macrothink $^{m}$}

- Also, NBCTs from Ohio proposed calculating teacher-student ratio with one "highly qualified" teacher for every 18 students in high-needs schools, will pose problems to over populated schools.

- Moreover, as reported in the summit, school principals may be faced with teachers who may not have the knowledge of community and culturally relevant pedagogy that will enable them to teach effectively and to work well with their students and colleagues. Many teachers enter classroom unprepared to work with learners that are as diverse as ever, including those who do not speak English as their primary language and those with learning or emotional disabilities, hearing impairments or those who are medically fragile and the teacher must teach them all.

- The NBCTs emphasized the fact that many teachers do not want to teach in schools where they cannot be successful. Such teachers know what it takes to be effective but most professional development programmes in the school do not provide them with what they needed.

- Moreover, it will be difficult for school administrators (principals) to prevent teachers with advanced degrees from prestigious colleges or teachers with degrees in "high market-value" subject such as mathematics, engineering and science from leaving teaching for jobs in other non-education fields at higher rates than to their colleagues without these educational qualities.

- The school principals cannot deprive teachers from going on retirement, maternity leave, sick leave, study leave among others despite the quality of the teacher.

- Most married teachers may not want to be retained in state's more rural and isolated schools.

\section{Support Needed By School Principals in Teacher Retention and Development}

Much is being asked of school leaders, especially principals, in the quest to raise standards and students achievement. To be successful, administrators need practical training to help them do their jobs more effectively from the start. They need ongoing professional development to keep them on top of innovations in education. Administrators also need continuous support from other school leaders, school staff, the community, the government among others. According to Barnnet, Rasberry, and Williams (2007), in the NBCTs summit, it was revealed that regrettably, too few administrators know how to support teachers' effort to educate all children at high level or how to nurture teacher leaders. They do not have the right training. The administrators therefore must be educated.

Most principals lack the skills in lesson plans. It was also reported in the NBCTs summit that some principals forced teachers to teach lesson plans that fail to take into account teachers' expertise and knowledge of the students' academic and social needs.

Some school principals do not have the training on how to make use of the available resources. Some principals also lack skills in relationship-building. They cannot be mentor or be efficient enough to know the right person to appoint as mentor especially for newly appointed or posted teachers. The NBCTs went a step further and proposed the establishment 
of a leadership academy within each district to prepare teachers and new administrators for successful collaborative leadership.

State Governments or Policymakers should be supportive to principals, grant them freedom to use their professional judgment, and a guarantee to work with like-minded and similar colleagues. NBCTs also believe that additional financial incentives should be offered to teachers who also teach in high-needs schools, and that, any teacher that have taught in such schools for a period of 3-5 years should receive additional transportation and gas allowances, signing and retention bonuses, salary supplements, moving expenses and college loan forgiveness for teachers and/or their families.

To make professional development more meaningful, States should consider strengthening such opportunities. Some strategies include:

- Enhancing funding

- Spending federal professional development fund more efficiently

- Aligning teacher professional development more closely with state academic standards and professional teaching standards.

The state government can also help principals to improve teacher retention particularly in rural schools by improving job satisfaction, salaries and maintaining student discipline problems.

\section{What the Nigerian Teachers Need To Be Retained In Schools}

A major source of teacher dissatisfaction in Nigeria arises from disparities between the teaching profession and other professions with respect to the time and mode of payment of salaries, fringe benefits, promotion prospects and working condition. What the typical low-income earning teacher yearns for is a sizable salary increase paid as at when due. This means that the payment of a living wage would significantly enhance Nigerian teachers' commitment and productivity.

School management and leadership style are also important factors which can motivate teachers to be retained in the school. Teachers feel highly motivated when they are consulted about decisions regarding their work. Unfortunately, too high a proportion of school principals in Nigeria are high-handed and autocratic in their dealing with teachers and unfair administrative and supervisory practices tend to undermine teacher morale (Duze, 2007). The attitude of inspectors towards teachers in supervising their work is another important work-related motivational factor for teacher retention.

The work environment is also an important determining factor in a teacher's motivation to be retained in the school system. The teachers' working environment in Nigeria has been described as the most impoverished of all sectors of the labour force. Facilities in most 
schools are dilapidated and inadequate and teacher-student ratio is a non-motivating factor for teachers. These contribute to school disorderliness in the school (Duze, 2011a).

There is a broad consensus among stakeholder respondents that there is definitely a teacher motivation crisis in Nigeria. The most serious symptoms of this crisis are low teacher output, high teacher turnover, regular strike actions, poor student performance, refusal of teachers to accept posting to rural areas, irregular class attendance and teacher absenteeism especially in rural areas. However, most government officials, particularly those at the state and local government levels, argue that teacher job satisfaction has improved in recent years. Even so, the overall level of job satisfaction remains low and far more needs to be done to raise teacher morale to a level that will impact significantly on the quality of basic education in Nigeria (Duze, 2011a).

The government free education policy with the attendant upsurge in enrolment has created the condition for employing teachers who are either poorly qualified or not committed to teaching. Universal Basic Education (UBE) has in effect made teaching an all comers job. Furthermore, Omar (2004) observed that the existing teacher recruitment and retention policies are not uniformly applicable at the three tiers of government in both public and private schools in the country. He pointed out that teachers are recruited as civil servants at the Federal level through the Federal Civil Service Commission but at the State and Local Government levels they are treated as public servants and employed by State Education Board or Commission. Such inconsistency means that teachers often do not enjoy uniform conditions of service and career prospects. According to Omar (2004), this accounts for the massive teacher turnover in Nigeria.

The overall level of motivation and incentives of Nigerian teachers has increased in recent times. Teachers now receive their salaries promptly and promotions have been effected for deserving teachers, except in some states like Delta State where promotion are not promptly effected of recent. The protracted economic crisis in Nigeria is the main reason for very low teacher attrition since there are hardly any alternative employment opportunities. Most attrition recorded in most States in Nigeria is due to retirement, study leave, transfer, illness and death.

Another non-motivating factor for teachers retention in school is that in most schools in Nigeria teachers are assigned classed and subjects purely on the basis of the vacancies and needs of the school rather than on teachers' interest, experience and background. School principals in most Nigerian secondary schools especially in the rural areas have problems in the retention of teachers. Female teachers especially the married ones reject transfers to rural schools. Even those who accept posting to rural schools, start applying for a transfer after a year or two. This explains why there are more teacher vacancies in rural than urban areas. For example, Table 1 represents the number of schools, total enrolment, number of teachers, and ratio in secondary schools in Delta State in 2010/2011. 
Table 1: Number of Schools, Total Enrolment, Teachers and Ratio in Secondary Schools in Delta State of Nigeria

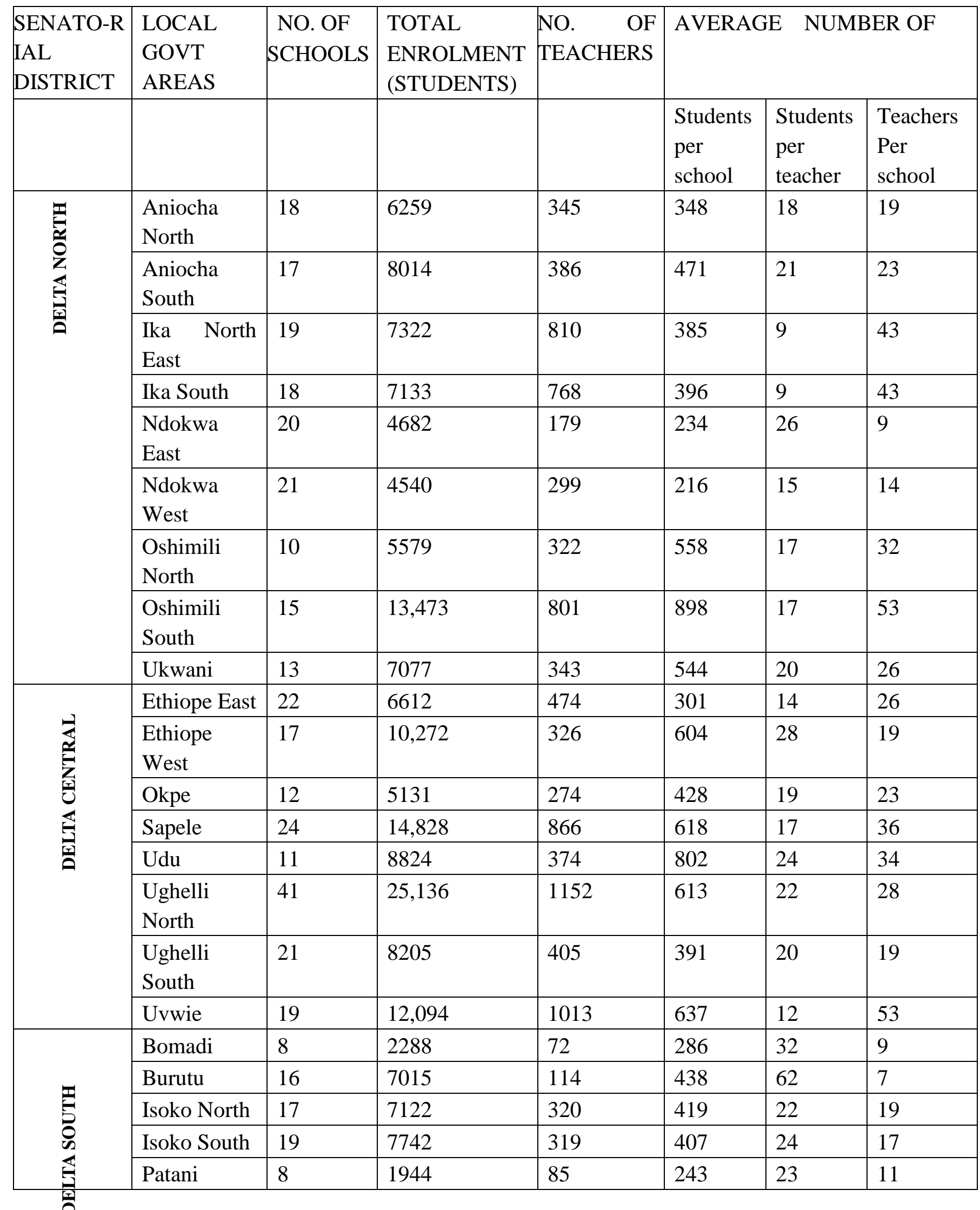




\begin{tabular}{|l|l|l|l|l|l|l|l|}
\hline & Warri North & 8 & 1596 & 102 & 200 & 16 & 13 \\
\cline { 2 - 7 } & Warri South & 21 & 16,491 & 1210 & 785 & 14 & 58 \\
\cline { 2 - 7 } & $\begin{array}{l}\text { Warri South } \\
\text { West }\end{array}$ & 5 & 973 & 97 & 195 & 10 & 19 \\
\hline
\end{tabular}

Table 1 showed that teacher populations in the urban areas were more than the rural areas in Delta state. For example local government areas comprising of urban areas have a higher population of teachers than local government areas with more rural areas. For instance, local government areas with urban areas are Ughelli North, Uvwie, Warri South while local government areas with rural areas are Burutu, Bomadi, Warri South West, Ndokwa East. Table 1 also revealed that while the teacher-student ratio in some local government areas like Ika North East, Ika South, and Warri South West is low, it is highest in Burutu. This could pose a problem to school principals in that local government area in retaining teachers. In other words, teachers in that local government area are over-worked. This can lead to poor learning environment, indiscipline, poor teacher-student relationship, inadequate infrastructure among others.

Arikewuyo and Adegbesan in Babalola and Ayeni (2009) are of the opinion that the quality of teacher resource depends on the recruitment, retention and development of professional teachers, and dedicated staff that would promote an optimum level of quality education since the ability of the schools to achieve its aim depends on the competence of its staff. It is therefore emphasized that deliberate and sincere efforts should be made to retain teachers in Nigeria schools in order to ensure continuity and effectiveness. The three areas that must be taken seriously if the best staff in school is to stay are condition of service, morale boosting, and efficiency.

Adeyemi in Babalola and Ayeni (2009) noted that staff will stay if there is the establishment of clear channel of communication with teacher; establishment of clear staff policy and principles of justice and fair play. Others are encouragement of teachers' participation in decision-making, welcoming teacher initiative (Duze, 2011a), provision of opportunities for promotion and in-service training, and assigning reasonable duties and workload to teachers.

Akikewuyo, (2006) identified some of the welfare services that can be provided by the Nigeria Government to prevent staff attrition to include adequate retirements benefit, pension scheme, medical services for teachers and their dependants, provision of counseling services to students, provision of cars to teachers, and end of year bonuses, among others.

\section{Conclusion}

This work emphasized the importance of the retention and development of quality teachers as it promotes students' academic performance. Thus, this study focused on various literature on theoretical retention strategies; the importance of comprehensive induction in teachers' 
retention and development; how improved working conditions retains quality teacher; the role of the school administrator in teachers' retention and development; problems facing school principals in teachers' retention and development in order to promote student achievements; supports needed by school principals in the retention and development of teachers; and what the Nigerian teachers need to be retained in schools.

It does appear that teacher poor condition of service, lack of additional incentive for teachers in rural and isolated schools, non involvement of teachers in decision making over matters concerning them, lack of infrastructures, principal administrative style, high student-teacher ratio, among others are the main reasons for teachers leaving secondary schools not only in Nigeria, but also in other parts of the world such as North and South Carolina, Ohio, Washington, Oklahoma among others.

Teachers will be encouraged to stay in schools when, they are involved in decision-making (Price, 2003; CEC, 2001); there is availability of resources to support the diverse needs of students and teachers (Feildings et al., 2003); there are additional incentives to teachers who teach in rural and isolated schools (Barnett et al., 2007); there is a positive school climate (National Education Association, 2003 and Hopkins, 2000); teachers workload is reduced (Fieldings et al., 2003); there is room for self development (Dipoala and Walther, 2003); student-teacher ratio is 18 students to every 1 qualified teacher (Barnett et al., 2007); principals implement a strong induction programme for teachers (Useem, 2001); there is cordial interpersonal relationship among students, parents, and teachers (Fergoson, 2003 and Wherry, 2003), among others.

\section{Recommendations}

Based on the conclusion drawn above, the following recommendations were made:

- States, in collaboration with school principals, should provide comprehensive induction for teachers to help develop novice teachers.

- School principals should make the school climate to be supportive for teacher to teach professionally.

- State school boards should enforce policies that provide for equitable distribution of resources to teachers and students in schools.

- School principals should encourage interpersonal relationship between staff and students. They should also promote a cordial school-community relationship.

- School principals should involve teachers in decision-making especially when such decisions concern them.

- School principals should ensure that the student-teacher ratio should not exceed what the teacher could manage. This is to allow for effective teaching and learning.

- Principals should ensure that teachers' workload is such that they can work effectively without undue stress. 


\section{Macrothink}

- The State government should grant additional incentive to teachers in rural schools and isolated schools and provide for professional development for both teachers and principals. School principals should be trained to be familiar with the available resources to support the diverse needs of students, families and staff.

\section{References}

Adeyemi in J.B. Babalola, \& A.O. Ayeni (2009). (Eds). Educational Management: Theories and Tasks. Ibadan, Macmillan

Arikewuyo, M.O. (2006). Elements of personnel management. In J.B. Babalola \& Ayeni A.O. (eds.). Educational Management Thought and Practice. Ibadan, Codal Publishers.

Arikewuyo \& Adegbesan in J.B. Babalola, \& A.O. Ayeni (2009). (Eds). Educational Management: Theories and Tasks. Ibadan, Macmillan

Barnett, B. Rasberry, M., \& Williams, A. (2007). Recruiting and Retaining quality teachers for High-Needs Schools: Insight from NBCT summits and other policy initiatives. Retrieved from www.teachingquality.org.

Claycomb, C., \& Hawley, W.D. (2000). Recruiting and Retaining Effective Teachers for

Urban Schools, National Partnership for Excellence and Accountability in Teaching.

Council for Exceptional Children (2000). Bright futures for exception learners. An agenda to achieve quality conditions for teaching and learning, VA: Reston

Council for Exceptional Children (2001). Implementing IDEA: A guide for principals.

Arlington, VA: Author.

Dipaola, M.F., \& Walther, T, C. (2003). Principals and special education: The critical

role of school leaders (COPSSE Document No. 1B-7E). Gainesville, FL: University of Florida, Center on Personnel Studies in Special Education.

Duze, C.O. (2011a). Students' and teachers' participation in decision-making and impact on school work and school internal discipline in Nigeria. African Research Review. 5(2):200-214.

Duze, C.O. (2011b). Parents' involvement in secondary school administration as a correlate of school effectiveness in the South-East Zone of Nigeria. Lwati: A Journal of Contemporary 


\section{Macrothink}

Journal of Sociological Research

ISSN 1948-5468

2013, Vol. 4, No.1

Research. 8(4): 16-29.

Duze, C.O. (2007). Teachers and students participation in decision-making: Impact on attitude to school work in Warri South LGA of Delta State. African Journal of Education and Developmental Studies. 4 (1):35-44.

Ferguson, D. (2003). Did you know about the differences between parent involvement

and family/community linkages? National institute for Urban School Improvement. Retrieved from http://www.inclusiveschools.org/parent involvement.pdf.

Fielding, C., \& Simpson, C. (2003). Four ways to support special educators in keeping

Good Teachers. In M. Scherer (Ed.) Association for Supervision and Curriculum Development. VA: Alexandria.

Harrison, R. (2005). Learning and development. CIPD publishing. Dp.5 ISBN 1843980509.

Hopkins, G. (2000). Principals identify top ten leadership traits (Ed). Education World.

Retrieved from www.educationworld.com/a-admin/admin/admin190.shtml

Ingersol, R.M. \& Smith, T. (2004). Reducing teacher turnover: What are the components of effective induction? American Education Research Journal, 41(3), 687-714. Retrieved from www.education.Wisc.edu.../Borman\%20\&\%20Dowling\%2092008)\%202.pdf

Mayer, D.P., Mullens, J.E., \& Moore, M.J. (2000). Monitoring school quality: An indicator's Report (NCSE 2001-030).Washington D.C , NCES.

National Education Association (2003). Meeting the challenges of recruitment and retention. A guidebook on promising strategies to recruit and retain qualified and diverse teachers. NEA

Omar, I.A. (2004). Transforming Teacher Recruitment and Retention. Policies and Practices at the Basic Education Level: An NUT Perspective. Paper Presented at $2^{\text {nd }}$ teachers summit organized by National Teachers Institute Kaduna. February, 2004.

Price, M.J. (2003). Are you a moral booster? In keeping Good Teachers. Alexandria, VA:

Association for Supervision and Curriculum Development. In M. Scherer. (Ed.) Public Education Network. (2003). The voice of the New Teacher. Washington, DC. 
Redmond, B. (2010). Lesson 4: Expectancy Theory: Is there a link between my effort and

what $l$ want ? The Pennysylvania State University. Retrieved from https://cms.psu.edu

Scholl, R.W. (2002). Motivation: Expectancy Theory. The University of Rhode Island.

Retrieved from http://www.uri.edu/research/lrc/scholl/webnotes/motivation Expectancy.htm

Southern Regional Educational Board. (2002). Reduce your Losses: Help new teachers

become Veteran teachers. Atlanta, G.A: Author

Useem, B. (2001). How do effective principals keep their teachers? Philadephia Public

School Notebook. Philadelphia Education Fund. Philadelphia, PA: Retrieved from http://phileadfund.org/notebook/

Villar, A. (2004). Measuring the benefits and costs of mentor-based induction. In Steff, B .E.,Wolfe, M.P., Pasch,S.H.\& Enz, B.J.(2000). The Live Cycle of the Career

Teacher. Thousand Oaks, CA: Corwin Press.

Wherry, J. H. (2003). Did you know 10 things any school can do to build parent involvement.. Institute, Plus 5 great ways to fail? The parent institute, Retrieved from www.par-inst.com/educator/resources/10things/10things.php. 